\title{
Description of Caldalkalibacillus uzonensis sp. nov. and emended description of the genus Caldalkalibacillus
}

Correspondence
Juergen Wiegel
jwiegel@uga.edu

\author{
Weidong Zhao, ${ }^{1,2}$ Chuanlun L. Zhang, ${ }^{1,2}$ Christopher S. Romanek ${ }^{2,3}$ \\ and Juergen Wiegel ${ }^{4}$ \\ ${ }^{1}$ Department of Marine Sciences, University of Georgia, Athens, GA 30602, USA \\ ${ }^{2}$ Savannah River Ecology Laboratory, University of Georgia, Aiken, SC 29802, USA \\ ${ }^{3}$ Department of Geology, University of Georgia, Athens, GA 30602, USA \\ ${ }^{4}$ Department of Microbiology, University of Georgia, Athens, GA 30602, USA
}

An aerobic heterotrophic, flagellated and slightly curved rod-shaped bacterium, strain JW/WZ-YB58 ${ }^{\mathrm{T}}$, which tolerated high concentrations of CO (up to $90 \%$ ) in the head space, was isolated from a hot spring located in the Uzon Caldera (Kamchatka, Far East Russia) and was named 'Thermalkalibacillus uzonensis' (Zhao et al., 2006). Analysis of $16 \mathrm{~S}$ rRNA gene sequences suggested that JW/WZ-YB58 ${ }^{\mathrm{T}}$ instead represents a novel species of the genus Caldalkalibacillus (Xue et al., 2006), which previously contained only the type strain of the type species, Caldalkalibacillus thermarum $\mathrm{HA}^{\mathrm{T}}$, an aerobic, heterotrophic, thermophilic bacterium (Xue et al., 2006). The $16 \mathrm{~S}$ rRNA gene sequence of C. thermarum $\mathrm{HA}^{\mathrm{T}}$ was $96.5 \%$ similar to that of strain JW/WZ-YB58 ${ }^{\mathrm{T}}$ and $99 \%$ similar to that of Bacillus sp. TA2.A1 (Peddie et al., 2000), suggesting that strain JW/WZ-YB58 ${ }^{\mathrm{T}}$ represents a separate species of the genus Caldalkalibacillus. The next closest neighbour, Bacillus horti, showed 92-93\% 16S rRNA gene sequence similarity to Caldalkalibacillus strains (Fig. 1).

Physiological and biochemical properties of strain JW/WZ$\mathrm{YB}^{\mathrm{T}}{ }^{\mathrm{T}}$ were described in detail by Zhao et al. (2006). Major

The GenBank/EMBL/DDBJ accession number for the 16S rRNA gene sequence of strain JW/WZ-YB58 ${ }^{\top}$ is DQ221694. phospholipid fatty acids of strain JW/WZ-YB58 ${ }^{\mathrm{T}}$ included iso- $\mathrm{C}_{15: 0} \quad(24.5 \%)$, anteiso- $\mathrm{C}_{15: 0}(18.3 \%)$, iso- $\mathrm{C}_{16: 0}$ $(9.9 \%)$, iso- $\mathrm{C}_{17: 0}(17.5 \%)$, anteiso- $\mathrm{C}_{17: 0}(9.7 \%)$ and $\mathrm{C}_{16: 0}(7.6 \%)$. Strain JW/WZ-YB58 ${ }^{\mathrm{T}}$ and C. thermarum $\mathrm{HA}^{\mathrm{T}}$ shared many properties. For example, both were strictly aerobic, thermophilic, alkalitolerant, Gram-staining-positive, sporulating rods that were able to grow on a variety of organic substrates including yeast extract, carbohydrates and organic acids. Both species contained iso- $\mathrm{C}_{15: 0}(24.5-33.8 \%)$ and iso- $\mathrm{C}_{17: 0}(17.5-35.5 \%)$ as major phospholipid fatty acids and the $\mathrm{G}+\mathrm{C}$ contents of genomic DNA of both strains are about $45 \mathrm{~mol} \%$ (although one was determined using the HPLC method and the other by $T_{\mathrm{m}}$ ).

However, the two species differed significantly in several properties (Table 1). For example, in contrast to the type species of the genus C. thermarum, strain JW/WZ-YB58 ${ }^{\mathrm{T}}$ was motile, contained two to five peritrichously inserted flagella, and was unable to utilize alcohols and sugar alcohols (e.g. D-sorbitol, D-mannitol, glycerol) as carbon and energy sources. Strain JW/WZ-YB58 ${ }^{\mathrm{T}}$ also contained anteiso- $\mathrm{C}_{15: 0}$ as the second most abundant fatty acid and was catalase-reaction-negative (Table 1). Strain JW/WZ$\mathrm{YB}^{\mathrm{T}}{ }^{\mathrm{T}}$ is therefore assigned to a novel species of the genus Caldalkalibacillus, Caldalkalibacillus uzonensis sp. nov., and 


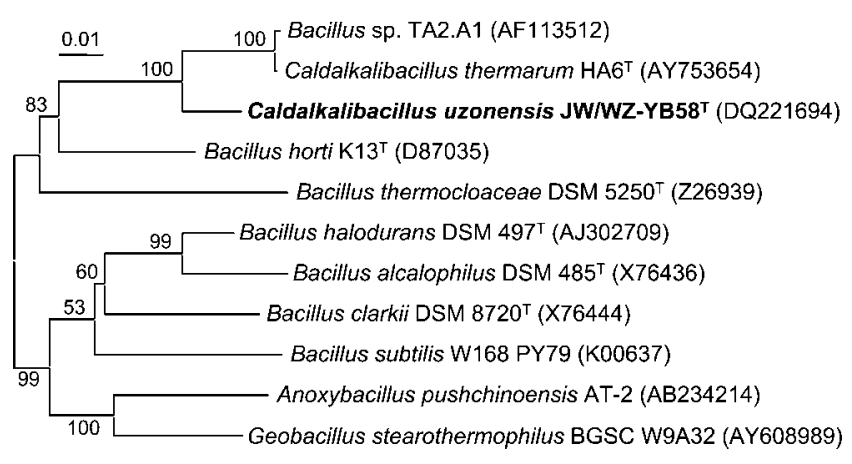

Fig. 1. Phylogenetic tree based on 1448 bp $16 \mathrm{~S}$ rRNA gene sequences. Relationships between sequences of strain JW/WZYB58 $^{\top}$ (Caldalkalibacillus uzonensis sp. nov.) and other related, mainly alkaliphilic and thermophilic strains were calculated using the neighbour-joining method with MEGA 3.1 software. Bootstrap analysis of 1000 replicates was performed and values greater than $50 \%$ are shown at nodes. Bar, 0.01 changes per nucleotide.

the last difference described above necessitates the emendation of the genus description.

\section{Emended description of the genus Caldalkalibacillus Xue et al. 2006}

The description is based on that provided by Xue et al. (2006), with the following amendments. The genus contains catalase-reaction-positive and catalase-reactionnegative species. Predominant cellular phospholipid fatty acids include iso- $\mathrm{C}_{15: 0}$, anteiso- $\mathrm{C}_{15: 0}$ and iso- $\mathrm{C}_{17: 0}$.

\section{Description of Caldalkalibacillus uzonensis sp. nov.}

Caldalkalibacillus uzonensis (u.zo.nen'sis. N.L. masc. adj. uzonensis pertaining to the isolation habitat of the type strain, the Uzon Caldera, east of Mt Uzon in Kamchatka, in Far East Russia).

The description is based on the previous detailed publication as 'Thermalkalibacillus uzonensis' (Zhao et al., 2006). Cells are Gram-type- (Wiegel, 1981) and Gramstaining-positive, straight to slightly curved rods, 0.7$0.8 \times 5.5-12 \mu \mathrm{m}$. Terminally located spherical spores $(1.2-$ $1.6 \mu \mathrm{m}$ in diameter) cause swelling of the mother cell. Cells are motile with two to five peritrichously inserted flagella. Growth is observed only under aerobic conditions. Colonies on nutrient broth agar are circular with entire edges and transparent. Swarming occurs when colonies age. Oxidase reaction, ONPG hydrolysis and gelatin hydrolysis are positive. Catalase reaction, Voges-Proskauer reaction, indole production, urea hydrolysis and starch hydrolysis are negative. At $\mathrm{pH}^{25}{ }^{\circ} \mathrm{C} 8.0$, the growth temperature range is $42-64{ }^{\circ} \mathrm{C}$, with optimum growth at $50-52{ }^{\circ} \mathrm{C}$. The $\mathrm{pH}^{25}{ }^{\circ} \mathrm{C}$ range is $6.4-9.7$, with optimum growth at $\mathrm{pH}^{25}{ }^{\circ} \mathrm{C} 8.2-8.4$ when grown at $52{ }^{\circ} \mathrm{C}$. $\mathrm{NaCl}$ is tolerated at $0-6 \%(\mathrm{w} / \mathrm{v})$. Cells grow on complex substrates (such as yeast extract), carbohydrates and acids but not on alcohols or sugar alcohols. Acid production occurs from trehalose, lactose, sucrose, arabinose and fructose. Major phospholipid fatty acids are iso- $\mathrm{C}_{15: 0}(24.5 \%)$, anteiso$\mathrm{C}_{15: 0}(18.3 \%)$, iso- $\mathrm{C}_{16: 0}(9.9 \%)$, iso- $\mathrm{C}_{17: 0}(17.5 \%)$, anteiso- $\mathrm{C}_{17: 0}(9.7 \%)$, and $\mathrm{C}_{16: 0}(7.6 \%)$. The $\mathrm{G}+\mathrm{C}$ content of genomic DNA of the type strain is $45 \mathrm{~mol} \%$ (HPLC; Mesbah et al., 1989). Cells do not grow

Table 1. Differentiating characteristics of strain JW/WZ-YB58 ${ }^{\top}$ and related species of the Firmicutes

Data for reference species were taken from Xue et al. (2006) (Caldalkalibacillus thermarum) and Yumoto et al. (1998) (Bacillus horti). +, Positive; W, weak; -, negative; S, spherical; E, ellipsoidal; T, terminal; ST, subterminal. None of the taxa grows at $10{ }^{\circ} \mathrm{C}$, and all three grow at $\mathrm{pH} 9$.

\begin{tabular}{|c|c|c|c|}
\hline Characteristic & JW/WZ-YB58 ${ }^{\mathrm{T}}$ & C. thermarum & B. horti \\
\hline \multicolumn{4}{|l|}{ Spore properties } \\
\hline Shape & s & s & $\mathrm{E}$ \\
\hline Position & $\mathrm{T}$ & $\mathrm{T}$ & ST \\
\hline Catalase & - & + & + \\
\hline \multicolumn{4}{|l|}{ Growth at/in: } \\
\hline $40{ }^{\circ} \mathrm{C}$ & - & - & + \\
\hline $50{ }^{\circ} \mathrm{C}$ & + & + & - \\
\hline pH 7 & + & - & + \\
\hline $10 \%(\mathrm{w} / \mathrm{v}) \mathrm{NaCl}$ & - & - & + \\
\hline Hydrolysis of starch & - & $\mathrm{w}$ & + \\
\hline Reduction of nitrate & - & - & + \\
\hline Major phospholipid fatty acids & $\begin{array}{c}\text { iso- }_{15: 0} \text {, anteiso- } \mathrm{C}_{15: 0} \text {, } \\
\text { iso- } \mathrm{C}_{17: 0}\end{array}$ & iso- $\mathrm{C}_{15: 0}$, iso- $\mathrm{C}_{17: 0}$ & $\begin{array}{l}\text { iso- } \mathrm{C}_{15: 0} \\
\text { anteiso- } \mathrm{C}_{15: 0}\end{array}$ \\
\hline DNA G $+C$ content $(\mathrm{mol} \%)$ & 45 & 45.2 & $40-41$ \\
\hline
\end{tabular}


chemolithoautotrophically on $1-5 \% \mathrm{v} / \mathrm{v} \mathrm{CO}$ or $5 \% \mathrm{CO}_{2}$ with or without $\mathrm{H}_{2}$ and do not oxidize $\mathrm{CO}$, even at low concentrations (100 p.p.m.). Cells growing under shaking tolerate up to $90 \%(\mathrm{v} / \mathrm{v}) \mathrm{CO}$ in the air-balanced headspace.

The type strain is JW/WZ-YB58 ${ }^{\mathrm{T}}$ (=ATCC BAA- $1258^{\mathrm{T}}$ $=$ DSM $17740^{\mathrm{T}}$ ), which was isolated from a microbial mat sample collected from the edges of the hot spring Zarvarzin II in the East Thermal Field of the Uzon Caldera, Kamchatka (Far East Russia).

\section{Acknowledgements}

This research was supported by a grant through National Science Foundation Microbial Observatory Program NSF-MCB 0238407 (J.W., C.S.R.) and partially supported by the Environmental Remediation Sciences Division of the Office of Biological and Environmental Research, US Department of Energy, through the Financial Assistant Award to the University of Georgia Research Foundation (C.S.R., C. L.Z.).

\section{References}

Mesbah, M., Premachandran, U. \& Whitman, W. B. (1989). Precise measurement of the $\mathrm{G}+\mathrm{C}$ content of deoxyribonucleic acid by highperformance liquid chromatography. Int J Syst Bacteriol 39, 159-167.

Peddie, C. J., Cook, G. M. \& Morgan, H. W. (2000). Sucrose transport by the alkaliphilic, thermophilic Bacillus sp. strain TA2.A1 is dependent on a sodium gradient. Extremophiles 4, 291-296.

Wiegel, J. (1981). Distinction between the Gram reaction and the Gram type of bacteria. Int J Syst Bacteriol 31, 88.

Xue, Y., Zhang, X., Zhou, C., Zhao, Y., Cowan, D. A., Heaphy, S., Grant, W. D., Jones, B. E., Ventosa, V. \& Ma, Y. (2006). Caldalkalibacillus thermarum gen. nov., sp. nov., a novel alkalithermophilic bacterium from a hot spring in China. Int J Syst Evol Microbiol 56, 1217-1221.

Yumoto, I., Yamazaki, K., Sawabe, T., Nakano, K., Kawasaki, K., Ezura, Y. \& Shinano, H. (1998). Bacillus horti sp. nov., a new Gramnegative alkaliphilic bacillus. Int J Syst Bacteriol 48, 565-571.

Zhao, W., Weber, C., Zhang, C. L., Romanek, C. S., King, G. M., Mills, G., Sokolova, T. \& Wiegel, J. (2006). Thermalkalibacillus uzonensis gen. nov. sp. nov., a novel aerobic alkali-tolerant thermophilic bacterium isolated from a hot spring in Uzon Caldera, Kamchatka. Extremophiles 10, 337-345. 